\title{
Assessment of Organochlorine Pesticide Residues in Vegetable Samples from Some Agricultural Areas in Togo
}

\author{
Lankondjoa Kolani*, Gbénonchi Mawussi, Komla Sanda \\ Laboratory for Research on Agro-Based Resources and Environmental Health, Advanced School of Agronomy, \\ University of Lomé, Lomé, Togo \\ Email: *klankondjoa@gmail.com
}

Received 5 February 2016; accepted 4 April 2016; published 7 April 2016

Copyright (C) 2016 by authors and Scientific Research Publishing Inc.

This work is licensed under the Creative Commons Attribution International License (CC BY).

http://creativecommons.org/licenses/by/4.0/

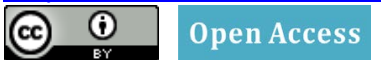

\section{Abstract}

The study was conducted to monitor the concentration of pesticide residues in three staple vegetables (tomato, cabbage, lettuce) collected from 12 prefectures belonging to 4 agro-ecological regions of Togo. A total of 150 samples of ripe tomato, cabbage and lettuce were collected from the study areas and analyzed for 20 OCPs (organochlorine pesticides) residues, which can be grouped into DDTs, Drins, Heptachlors, Chlordanes and HCHs. The data revealed that $100 \%$ of the analyzed vegetable samples were contaminated by one or more pesticide residues; $83.32 \%$ and $100 \%$ were below the maximum residue limits (MRLs) set par European Union and FAO/WHO respectively whereas $16.68 \%$ were above the EU (MRLs) adopted values. Overall, cabbage contained the highest number of samples with pesticide residues above the MRLs followed by tomato, whilst none of lettuce samples contained pesticide residues above the MRLs. It is therefore proposed to perform continuous monitoring studies of pesticide residues in vegetables cultivated in Togo.

\section{Keywords}

Togo, Organochlorine Pesticides, Residues, Vegetables, Maximum Residue Limit (MRL)

\section{Introduction}

Pesticides are part of the control means available to farmers to combat insect pests. Today, it is estimated that as much as $45 \%$ of the world's crop is destroyed by insect pests and plant diseases. Thus in order to meet the food demand of the world, it is essential to use plant protection strategies, based on various approaches including among others the use of commercial pesticides [1].

\footnotetext{
"Corresponding author.
}

How to cite this paper: Kolani, L., Mawussi, G. and Sanda, K. (2016) Assessment of Organochlorine Pesticide Residues in Vegetable Samples from Some Agricultural Areas in Togo. American Journal of Analytical Chemistry, 7, 332-341. 
Organochlorine pesticides (OCPs) have been commonly used in agriculture in the past. But since the 1950s, the OCPs have become of much concern for human health and environment, and the Stockholm Convention on persistent organic pollutants (POPs) [2] listed most of them as banned (Annex A POPs) or at least severely restricted chemicals (Annex B POPs). In fact, because of their prolonged persistence, long-range transport nature, high toxicity, as well as bioaccumulative tendency, they can cause chronic toxicity in animals and human via air, water and food intake [3] [4]. Thus, exposure to OCPs has been associated with human health risk of arthritis, skin disease, bone disorder, endocrine disruption, developmental abnormalities, reproduction failure, cancer and nerve disorder. For humans, food is the major pathway for exposure to OCPs [5] [6].

Because of their harmful effects, OCPs are banned in developed countries since 1980s [7]-[9] and their monitoring in food has been conducted in several countries in order to study route exposure of human to OCPs through dietary intake [10]-[12]. However, control programs for pesticide residues in the developing countries are often limited if not absent because of the lack of adequate infrastructure and non-enforcement of legislation.

Recent monitoring in Ghana revealed contamination of vegetables with OCPs at worrying levels that exceeded the accepted maximum residue limit [13]-[15]. Even OCPs not registered for use on vegetables were found in food [16]. In addition, non-target crops were also contaminated with high levels of OCPs [17], indicating their widespread application in this country.

In Togo, the regulatory framework governing the use of organochlorine pesticides is the Decree $\mathrm{N}^{\circ}$. 31/APR/ SG/DA of September 21, 2004 [18] that prohibits the import and use of organochlorines in Togo. Particularly the following POPs: Aldrin, endrin, dieldrin, DDT, mirex, toxaphene, hexachlorobenzene (HCB), chlordane and heptachlor. Lindane, chlordecone and endosulfan shall be added to the list. However, the banned OCPs may still continue entering the country since the local pesticide market for smallholder farmers is dominated by the informal sector that offers cheaper pesticides to farmers including those producing vegetables. Indeed the vegetables production sector in Togo is intensively consuming pesticides and it is therefore a public health concern to ensure that vegetables produced in the country are of good sanitary quality. In addition data on recent status of OCPs residue in vegetable from Togo are very scarce. Therefore, the aim of our study is to investigate the level of contamination of vegetables by OCPs in major vegetable production areas of Togo.

\section{Materials and Methods}

\subsection{Study Areas}

The study was conducted in 12 prefectures belonging to 4 agro-ecological regions of Togo (Figure 1). The areas selected for sampling are major areas with high vegetable production activity that develops around water sources (rivers, streams, garden wells) and extends throughout the year depending on demand and agro-ecological characteristics of crops.

\subsection{Sample Collection}

A total of one hundred fifty (150) samples of vegetable were collected from the study areas including 55 samples of cabbage, 55 samples of ripe tomato and 40 samples of lettuce. These vegetables were chosen because they are very common in Togolese diets and need little or virtually no processing before consumption. For each prefecture, 2 composite samples of 1 - $2 \mathrm{~kg}$ of vegetables were constituted by blending from vegetables samples collected from the main producing sites of localities where the vegetables were ready for sale. The composite samples were chopped and washed with distilled water, wrapped with aluminum foil, labeled, placed in an ice chest box and then were transported to the laboratory (Ghana Atomic Energy commission GAEC) and stored at $-20^{\circ} \mathrm{C}$ for further analysis.

\subsection{Pesticide Extraction and Clean up}

Frozen chopped samples were kept at room temperature for about 3 hours and ground at full speed using a warring blender. Extraction of vegetable samples was carried out according to procedures described by Bempah et al. 2012 [15] with slight modification. Sub-samples (10 g) of homogenize sample was weighed into a clean, dry and labeled conical flask containing $30 \mathrm{~g}$ of anhydrous sodium sulfate $\left(\mathrm{Na}_{2} \mathrm{SO}_{4}\right)$ and $5 \mathrm{~g}$ of sodium hydrogen carbonate $\left(\mathrm{NaHCO}_{3}\right)$ and thoroughly mixed. The mixture was extracted with $3 \times(30 \mathrm{ml})$ ethyl acetate-hexane $(2: 1 \mathrm{v} / \mathrm{v})$ by shaking for $30 \mathrm{~min}$ using a sonicator (BRANSONIC 220). The supernatant was concentrated to near 


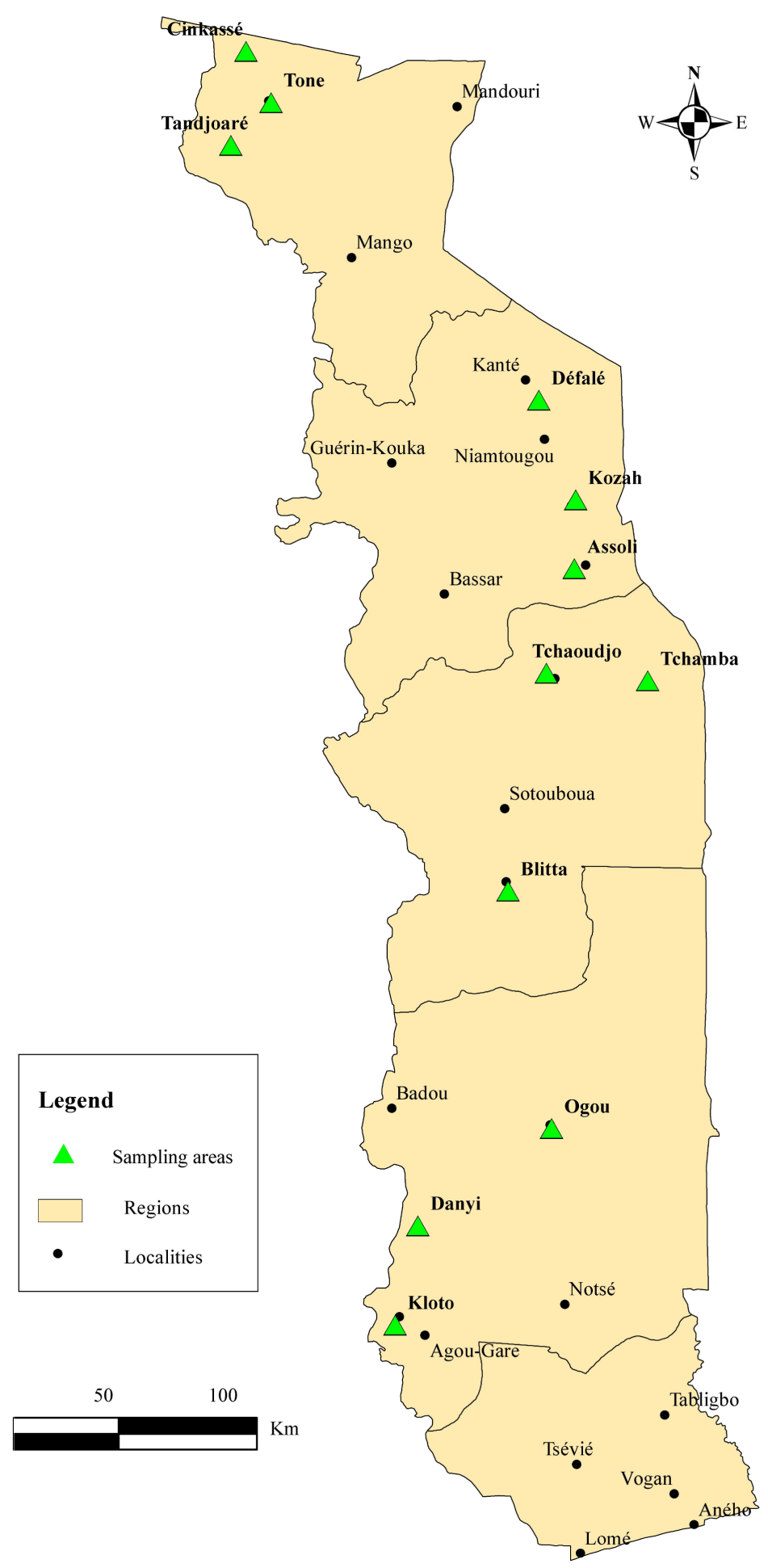

Figure 1. Map of Togo showing sampling areas.

dryness using a vacuum rotary evaporator (BÜCHI Heating Bath B-490) with a water bath at $45^{\circ} \mathrm{C}$. The sample was purified on a complex of adsorbents (deactivated florisil, $4 \mathrm{~g}$; anhydrous sodium sulfate, $1 \mathrm{~g}$ and activated charcoal, $2 \mathrm{~g}$ ) and eluted with $40 \mathrm{ml}$ portions of hexane mixtures and evaporated to dryness. The extract was picked in $2 \mathrm{ml}$ ethyl acetate into a GC vial and sealed for subsequent quantification using gas chromatograph. 


\subsection{Pesticide Analysis}

Measurements were carried out on a Shimadzu GC 2010, gas chromatograph equipped with an Electron Capture Detector. The chromatographic separation was done on an SGE BPX-5 of 60 m capillary column with $0.25 \mathrm{~mm}$ internal diameter and $0.25 \mu \mathrm{m}$ film thickness and equipped with $1 \mathrm{~m}$ retention gap $(0.53 \mathrm{~mm}$, deactivated). The oven temperature program was set as follows: Initial temperature was set at $90^{\circ} \mathrm{C}$ for 3 min and ramped at $30^{\circ} \mathrm{C} / \mathrm{min}$ to $200^{\circ} \mathrm{C}$ for $15 \mathrm{~min}$ and then to $265^{\circ} \mathrm{C}$ at a rate of $5^{\circ} \mathrm{C} / \mathrm{min}$ for $5 \mathrm{~min}$ then to $275^{\circ} \mathrm{C}$ at the rate of $3^{\circ} \mathrm{C} /$ min and allowed to stay for $15 \mathrm{~min}$ giving a total run time of $58 \mathrm{~min}$. The injector setting is a pulsed splitless mode with a temperature of $250^{\circ} \mathrm{C}$ at a pressure of $1.441 \mathrm{bar}$. Pulsed pressure was $4.5 \mathrm{bar}$, pulsed time $1.5 \mathrm{~min}$, purge flow of $55.4 \mathrm{ml} / \mathrm{min}$ with a purge time of $1.4 \mathrm{~min}$. The detector temperature was $300^{\circ} \mathrm{C}$ in "constant makeup flow" mode ( $30 \mathrm{ml} / \mathrm{min}$ of Nitrogen gas). The residue of pesticide was identified based on comparison of the measured relative retention times to those of known standards. The residue levels of organochlorine pesticides were quantitatively determined by the external standard method using peak area. Measurement was carried out within the linear range of the detector. The peak areas whose retention times coincide with the standards were extrapolated on their corresponding calibration curves to obtain the concentration.

\subsection{Quality Control}

The quality of organochlorine pesticides was assured through the analysis of solvent blanks, procedure blanks and duplicate samples. The method was optimized and validated using spiked together with the internal standard to evaluate the recovery of compounds [19]. The recoveries of internal standards ranged between $87 \%$ and $104 \%$ for all the organochlorine pesticide. The limit of detection was $0.001 \mathrm{ng} \cdot \mathrm{g}^{-1}$.

\section{Results and Discussion}

The level of individual OCPs in vegetables is reported on Figure 2 and Table 1. All concentrations of OCPs are expressed in $\mathrm{ng} \cdot \mathrm{g}^{-1}$ on a whole basis.

The different vegetables sampled (tomato, cabbage and lettuce) were analysed for the following Persistent OCPs compounds: HCHs, Drins, Heptachlors, Chlordanes, DDTs. Overall, total concentration of $\Sigma$ OCPs ranged between $<0.001$ to $119.28 \mathrm{ng} \cdot \mathrm{g}^{-1}$ with the mean of $6442 \mathrm{ng} \cdot \mathrm{g}^{-1}$ (Figure 2). On the OCPs analyzed, the concentration of total HCHs was found to be higher with an average concentration of $5.847 \mathrm{ng} \cdot \mathrm{g}^{-1}$ followed by total DDTs, Chlordanes, Drins and heptachlors which recorded concentrations of $0.27,0.26,0.25$ and $0.012 \mathrm{ng} \cdot \mathrm{g}^{-1}$ respectively (Figure 2(a)). Among the detected and quantified pesticides, Drins accounted $31.11 \%$ of the total OCPs, followed by HCHs and DDTs (23.3\%), Chlordanes (16.50\%) and Heptachlors (2.91\%) (Figure 2(b)).

Table 1 illustrates the level of pesticide concentration in the three vegetables analyzed. The average total concentration of OCPs in tomato, cabbage, and lettuce was $8 \pm 1.203 \mathrm{ng} \cdot \mathrm{g}^{-1}, 16.436 \pm 2.717 \mathrm{ng} \cdot \mathrm{g}^{-1}, 6.29 \pm 4.005$ $\mathrm{ng} \cdot \mathrm{g}^{-1}$, respectively. $\Sigma$ Drins, $\Sigma$ Chlordanes, and $\Sigma$ DDTs were detected in all three vegetables with the highest concentration below $3 \mathrm{ng} \cdot \mathrm{g}^{-1}$. Similarly, Lindane was found in only tomato and lettuce. The $\Sigma$ Heptachlors were found in cabbage and lettuce in lower concentrations (below $1 \mathrm{ng} \cdot \mathrm{g}^{-1}$ ). However, higher level was observed with $\Sigma \mathrm{HCHs}$ in tomato with the highest concentration of $11.307 \mathrm{ng} \cdot \mathrm{g}^{-1}$ and in cabbage with the highest concentration

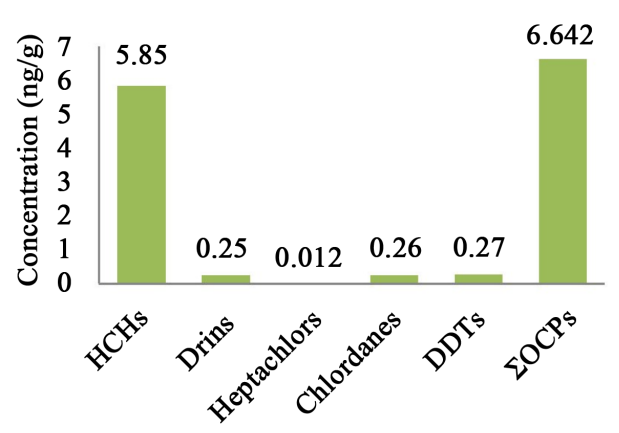

(a)

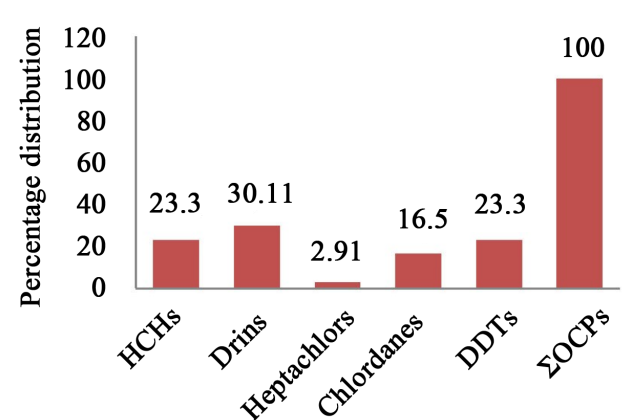

(b)

Figure 2. (a) Concentration (ng. $\mathrm{g}^{-1}$ ) of OCPs in studied vegetables. (b) Distribution (\%) of OCPs in studied vegetables. 
Table 1. Pesticide residue concentrations in the tested vegetables $\left(\mathrm{ng} \cdot \mathrm{g}^{-1}\right)$.

\begin{tabular}{|c|c|c|c|c|c|c|}
\hline \multirow{2}{*}{ Pesticide } & \multicolumn{2}{|c|}{ Tomato $(n=55)^{a}$} & \multicolumn{2}{|c|}{ Cabbage $(n=55)$} & \multicolumn{2}{|c|}{ Lettuce $(n=40)$} \\
\hline & Range & $\operatorname{Mean} \pm \mathrm{SE}^{\mathrm{b}}$ & Range & Mean \pm SE & Range & Mean \pm SE \\
\hline Alpha-HCH & $<0.001-0.156$ & $0.073 \pm 0.006$ & $<0.001-0.176$ & $0.064 \pm 0.005$ & $<0.001-0.170$ & $0.069 \pm 0.023$ \\
\hline Beta-HCH & $<0.001-10.832$ & $1.626 \pm 0.337$ & $<0.001-90.673$ & $14.544 \pm 2.507$ & $<0.001-2.087$ & $0.330 \pm 0.26$ \\
\hline Gamma-HCH & $<0.001-0.026$ & $0.002 \pm 0.000$ & $<0.001$ & $<0.001$ & $<0.001-0.053$ & $0.017 \pm 0.008$ \\
\hline Delta-HCH & $<0.001-0.313$ & $0.089 \pm 0.010$ & $<0.001-2.983$ & $0.507 \pm 0.079$ & $0.150-0.324$ & $0.201 \pm 0.019$ \\
\hline$\sum \mathrm{HCHs}$ & $<0.001-11.307$ & $1.79 \pm 0.354$ & $<0.001-93.832$ & $15.115 \pm 2.592$ & $0.150-2.634$ & $0.617 \pm 0.312$ \\
\hline Aldrin & $<0.001-0.263$ & $0.166 \pm 0.010$ & $<0.001-0.352$ & $0.177 \pm 0.010$ & $0.183-0.380$ & $0.262 \pm 0.022$ \\
\hline Dieldrin & $<0.001-0.194$ & $0.018 \pm 0.005$ & $<0.001-0.086$ & $0.011 \pm 0.002$ & $<0.001-0.010$ & $0.001 \pm 0.001$ \\
\hline Endrin & $<0.001-0.161$ & $0.023 \pm 0.004$ & $<0.001-0.239$ & $0.055 \pm 0.008$ & $<0.001-0.310$ & $0.039 \pm 0.038$ \\
\hline$\sum$ Drins & $<0.001-0.618$ & $0.207 \pm 0.015$ & $<0.001-0.677$ & $0.243 \pm 0.02$ & $0.183-0.7$ & $0.302 \pm 0.061$ \\
\hline Heptachlor & $<0.001$ & $<0.001$ & $<0.001-0.081$ & $0.007 \pm 0.002$ & $<0.001-0.254$ & $0.032 \pm 0.031$ \\
\hline Cis heptachlor & $<0.001$ & $<0.001$ & $<0.001-0.154$ & $0.014 \pm 0.004$ & $<0.001$ & $<0.001$ \\
\hline Trans-heptachlor & $<0.001$ & $<0.001$ & $<0.001-0.013$ & $0.001 \pm 0.000$ & $<0.001$ & $<0.001$ \\
\hline$\sum$ Heptachlors & $<0.001$ & $<0.001$ & $<0.001-0.248$ & $0.022 \pm 0.006$ & $<0.001-0.254$ & $0.032 \pm 0.031$ \\
\hline Cis-Chlordane & $<0.001$ & $<0.001$ & $<0.001$ & $<0.001$ & $<0.001$ & $<0.001$ \\
\hline Trans-Chlordane & $<0.001$ & $<0.001$ & $<0.001-0.292$ & $0.052 \pm 0.008$ & $<0.001-0.081$ & $0.014 \pm 0.01$ \\
\hline Trans-Nonachlor & $<0.001-0.367$ & $0.152 \pm 0.016$ & $<0.001-1.294$ & $0.463 \pm 0.038$ & $<0.001-0.454$ & $0.101 \pm 0.066$ \\
\hline$\sum$ Chlordanes & $<0.001-0.367$ & $0.152 \pm 0.016$ & $<0.001-1.586$ & $0.515 \pm 0.047$ & $<0.001-0.535$ & $\mathbf{0 . 1 1 5} \pm \mathbf{0 . 0 7 7}$ \\
\hline p,p-DDT & $<0.001-0.527$ & $0.165 \pm 0.021$ & $<0.001-0.643$ & $0.190 \pm 0.000$ & $<0.001-0.681$ & $0.232 \pm 0.1$ \\
\hline o,p-DDT & $<0.001$ & $<0.001$ & $<0.001-0.010$ & $0.001 \pm 0.000$ & $<0.001$ & $<0.001$ \\
\hline p,p-DDE & $<0.001-0.253$ & $0.080 \pm 0.010$ & $<0.001-0.595$ & $0.215 \pm 0.021$ & $<0.001-0.368$ & $0.081 \pm 0.047$ \\
\hline p,p-DDD & $<0.001$ & $<0.001$ & $<0.001-0.034$ & $0.003 \pm 0.001$ & $<0.001$ & $<0.001$ \\
\hline o,p-DDD & $<0.001$ & $<0.001$ & $<0.001-0.236$ & $0.042 \pm 0.008$ & $<0.001-0.187$ & $0.023 \pm 0.023$ \\
\hline o,p-DDE & $<0.001$ & $<0.001$ & $<0.001$ & $<0.001$ & $<0.001$ & $<0.001$ \\
\hline$\sum$ DDTs & $<0.001-0.78$ & $0.245 \pm 0.031$ & $<0.001-1.518$ & $0.451 \pm 0.052$ & $<0.001-1.236$ & $0.104 \pm 0.171$ \\
\hline$\sum \mathrm{OCPs}$ & $<0.001-13.072$ & $2.394 \pm 0.33$ & $<0.001-97.861$ & $16.436 \pm 2.717$ & $0.333-5.08$ & $1.17 \pm 0.653$ \\
\hline
\end{tabular}

${ }^{a}$ n: number of samples; ${ }^{b} \mathrm{SE}$ : standard error $=\mathrm{SD} / \sqrt{ }$.

of $93.382 \mathrm{ng} \cdot \mathrm{g}^{-1}$ and at low level in lettuce (highest concentration of $2.634 \mathrm{ng} \cdot \mathrm{g}^{-1}$ ). Within the HCHs group, $\beta$ $\mathrm{HCH}$ was found in the highest level in all three vegetables analyzed. Similarly Aldrin, Heptachlor, Trans-Nonachlor, p,p-DDT, respectively among Drins, Heptachlors, Chlordanes and DDT groups, had the highest concentrations when present in the tested vegetables.

The highest contamination frequency (Figure 3) of $\Sigma \mathrm{HCHs}$ was found in lettuce (100\%) followed by tomato and cabbage that recorded the same contamination rate (72.72\%) (Figure 3(a)). The same pattern of contamination was observed with $\Sigma$ DDTs (Figure 3(e)). Within the $\Sigma \mathrm{HCH}, \alpha-\mathrm{HCH}(54.5 \%)$ was found to be dominant contaminant in tomato, while $\alpha-\mathrm{HCH}$ and $\delta$-HCH were dominant contaminants in cabbage with contamination frequency of $63.6 \%$, and $\delta$-HCH (100\%) in lettuce. Alongside, p,p-DDT (50\%) and pp-DDE (54.5\%) were found to be dominant contaminant in lettuce and in cabbage respectively, and pp-DDT and pp-DDE were the most frequent pesticide residues found in tomato with a contamination rate of $36.4 \%$. Lettuce, tomato and cabbage were contaminated by $\Sigma$ Drins at the contamination rate of $100 \%, 90 \%$ and $81.81 \%$ respectively with Aldrin the most frequent residue found in the three vegetables $(87.5 \%, 81.8 \%$ and $72.72 \%$ respectively for lettuce, cabbage and tomato) (Figure 3(b)). $\Sigma$ Chlordanes was found at higher frequency in cabbage (90.90\%), at a 


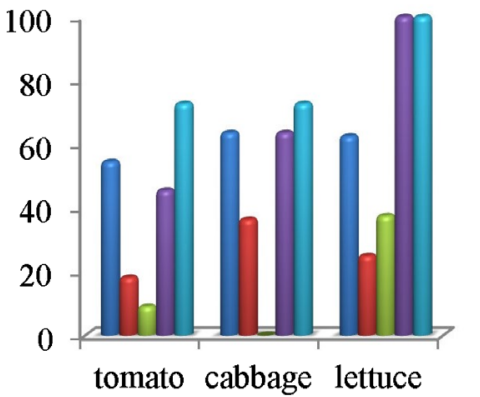

(a)

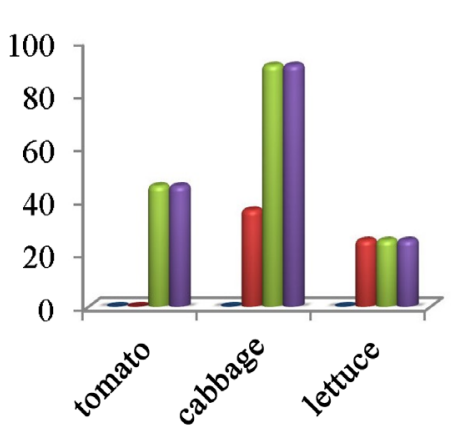

(c)

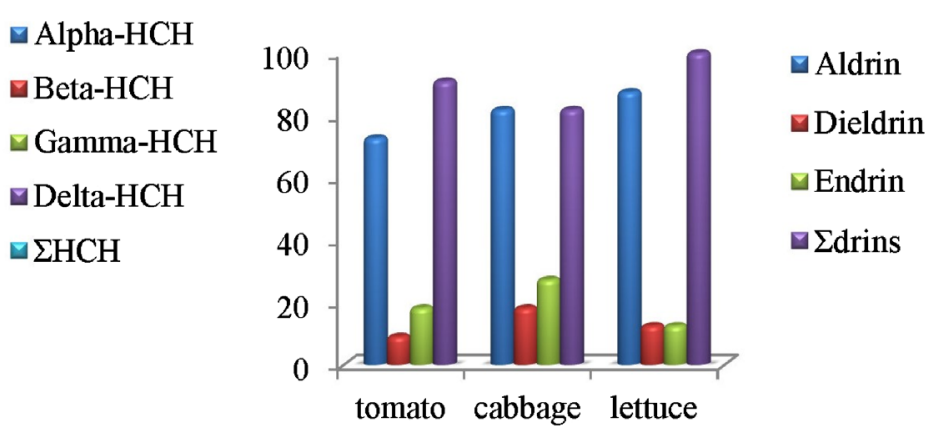

(b)

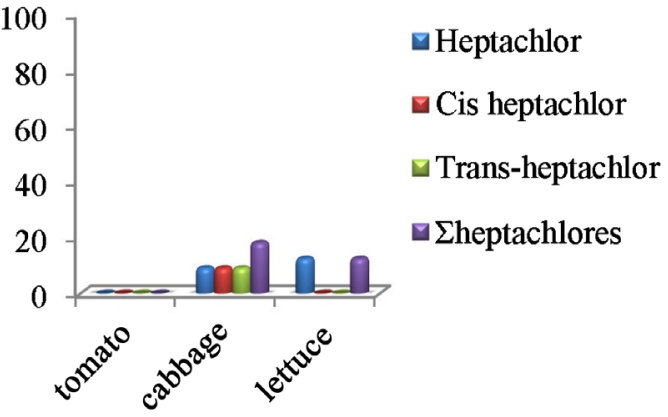

(d)

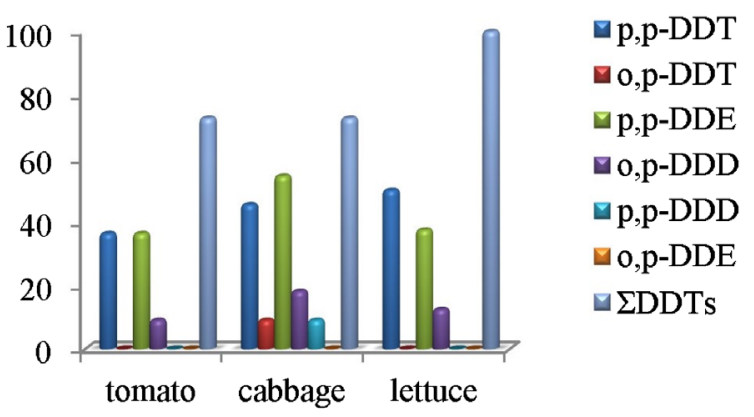

(e)

Figure 3. Pesticide residues frequency in tested vegetables. (a) HCHs; (b) Drins; (c) Heptachlores; (d) Chlordanes; (e) DDTs.

relatively medium frequency in tomato (45.5\%) and at a low frequency in lettuce (25\%) and the same pattern contamination was observed with the dominant residue of this OCP (Figure 3(c)). $\Sigma$ Heptachlors was found only in cabbage and lettuce at low contamination rate (18.18\% and 12.5\% respectively) (Figure 3(d)).

The observed concentration of OCP compounds in this study was compared with recommended maximum residue limits (MRLs) set by European commission (2015) and WHO (2015) (Table 2). The comparison of obtained results with MRLs indicated that studied vegetables in this study had residue levels of OCPs far much below MRLs except for $\mathrm{EHCHs}$ for which $9.1 \%$ of tomato samples and $36.4 \%$ of cabbage samples exceeded EU MRLs.

The occurrence of pesticide residues is listed in Figure 4. None of the analyzed vegetable samples was residue-free. All of them were contaminated with at least one OCP; most samples had two or more residues. Among all three vegetables studied, cabbage was the most contaminated and it had multiple OCPs; hence $72.72 \%$ of cabbage samples collected were contaminated with more than 4 residues, whereas $9.09 \%$ of samples were contaminated with 4 residues and 2 residues respectively. Following cabbage was lettuce with 50\%, 37.5\% and 12.5\% of samples being contaminated with more than 4 residues, 4 residues and 2 residues respectively. As for tomato, $18.18 \%, 45.45 \%, 9.09 \%$ and $27.27 \%$ of samples were respectively contaminated with more than 4 residues, 4 residues, 3 residues and 2 residues (Figure 4). 
Table 2. Maximum residue limits (MRLs) of OCPs in vegetables.

\begin{tabular}{|c|c|c|c|c|c|c|c|c|c|c|c|c|}
\hline \multirow[b]{2}{*}{ Pesticide } & \multicolumn{4}{|c|}{ Tomato $(n=55)^{a}$} & \multicolumn{4}{|c|}{ Cabbage $(n=55)^{\mathrm{a}}$} & \multicolumn{4}{|c|}{ Lettuce $(n=40)^{a}$} \\
\hline & $\begin{array}{c}\text { MRL } \\
\text { (EU) }\end{array}$ & $\begin{array}{l}\text { MRL } \\
\text { (FAO) }\end{array}$ & $\begin{array}{c}>\text { MRL } \\
\text { (EU) }\end{array}$ & $\begin{array}{l}>\text { MRL } \\
\text { (FAO) }\end{array}$ & MRL & $\begin{array}{l}\text { MRL } \\
\text { (FAO) }\end{array}$ & $\begin{array}{c}>\text { MRL } \\
\text { (EU) }\end{array}$ & $\begin{array}{l}>\text { MRL } \\
\text { (FAO) }\end{array}$ & MRL & $\begin{array}{c}\text { MRL } \\
\text { (FAO) }\end{array}$ & $\begin{array}{c}>\text { MRL } \\
\text { (EU) }\end{array}$ & $\begin{array}{l}>\text { MRL } \\
\text { (FAO) }\end{array}$ \\
\hline Lindane & 10 & 2000 & 0 & 0 & 10 & - & 0 & - & 10 & - & 0 & - \\
\hline$\sum \mathrm{HCHs}$ & 10 & - & $9.1 \%$ & - & 10 & - & $36.4 \%$ & - & 10 & - & 0 & 0 \\
\hline Aldrin + Dieldrin & 10 & 100 & 0 & 0 & 10 & 50 & 0 & 0 & 10 & 50 & 0 & 0 \\
\hline Endrin & 10 & 50 & 0 & 0 & 10 & 50 & 0 & 0 & 10 & 50 & 0 & 0 \\
\hline$\sum$ Heptachlors & 10 & 20 & 0 & 0 & 10 & 50 & 0 & 0 & 10 & 50 & 0 & 0 \\
\hline$\sum$ Chlordanes & 10 & 20 & 0 & 0 & 10 & 20 & 0 & 0 & 10 & 20 & 0 & 0 \\
\hline$\sum$ DDTs & 50 & 1000 & 0 & 0 & 50 & 1000 & 0 & 0 & 50 & 1000 & 0 & 0 \\
\hline
\end{tabular}

${ }^{a}$ n: number of samples.

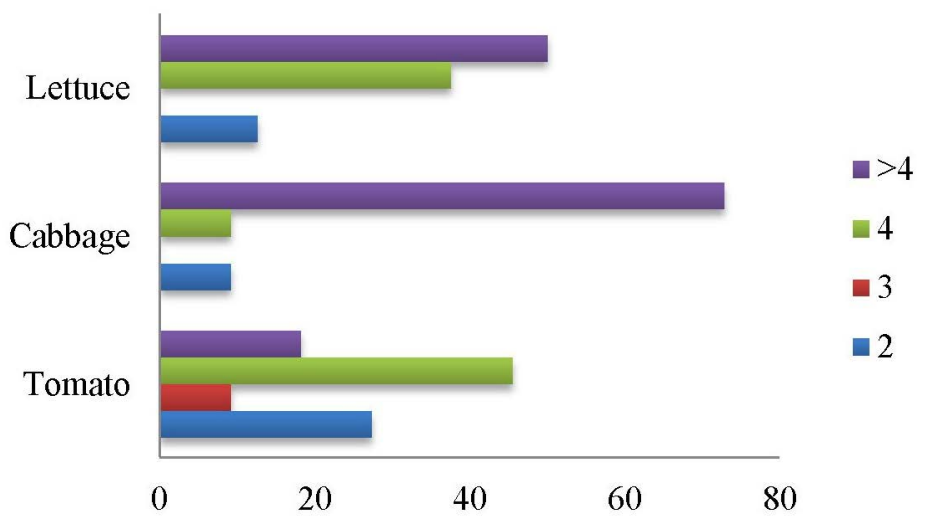

Figure 4. Vegetables with multiple pesticide residues in samples analyzed.

The results of the present study on pesticide residues revealed that a broad range of OCPs contaminated vegetables indicating a wide use of OCPs in Togo. However the level of OCPs residues in the tested vegetables, were found to be low in most vegetables samples as concentrations were below MRLs set par the European commission (2015) [20] and WHO (2015) [21]. In comparison, the levels of the residues in the tested vegetables were far below those previously reported in Ghana [13] [15] [17] and in India [22] [23] indicating that in the case of Togo, OCPs might probably originate from past uses instead of current application on cultivated vegetables [7]. Concentration of $\mathrm{\Sigma HCHs}$ in tomato samples from the Prefecture de Tchaoudjo and in cabbage samples from Préfecture de Tchaoudjo, Préfecture de l’Ogou, Préfecture de Kloto and Préfecture de Danyi was however found to be relatively high, exceeding EU MRL. These vegetables would have been grown on high polluted site or contaminated by leaching from a heavily polluted nearby site. This indicates that HCH was used in Togo extensively before its use in the agricultural sector was banned. HCHs are among the most widely used and most readily detected OCPs in environmental samples [24] and they were found at relatively high proportion (88.08\% of $\Sigma$ OCPs) in studied vegetables. When detectable, individual $\alpha, \beta, \gamma$ and $\delta$ isomers of HCH were found to contribute $\sim 0 \%-11 \%, 53 \%-96 \%, 0 \%-2 \%$ and $2 \%-4 \%$ respectively. $\beta$ - $\mathrm{HCH}$ has the lowest water solubility and vapor pressure, and is the most stable and relatively resistant to microbial degradation [25]. It has, as well higher affinity towards the lipidic fraction of plants cell walls and the most likely mechanisms of $\mathrm{HCH}$ accumulation in plants is sorption of soil HCH on roots [26]. In addition, after a long period of weathering, $\alpha$ - and $\gamma$-HCHs could be transformed into $\beta$-HCH [27]. It is these properties of $\beta$-HCH relative to other HCHs that most likely accounted for the greater proportion of $\beta$ - $\mathrm{HCH}$ in the samples. The relatively high proportion of $\beta$-HCH observed indicated that the HCH as well as other OCPs found, was mainly due to historical use as a pesticide [28].

Because of their effectiveness, OCPs have been widely used as agricultural pesticides whether for food or 
cash crops [29] [30]. In West Africa, OCPs were mostly used on cocoa plantations, on vegetable farms, and for the control of stemborers in maize [31]. These pesticides are still being used clandestinely in some developing countries in vegetable growing [15]-[17] though they have been banned in most countries [29] [30]. This can be explained by the fact that farmers in most developing countries have low levels of education and disregard the harmful effects of these pesticides on the environment. Having experienced the effectiveness of OCPs in the past, they would therefore be inclined to resort to clandestine supply of these products. A wide awareness on the negative impact of these pesticides on health and the environment is therefore necessary and must be continuously implemented within the farmer population of developing countries to deter and enable broad adoption of the regulation tests in this respect in these countries. It also calls for improved tighter regulation in the sale of pesticides as well as for education of farmers and the implementation of integrated pest management methods.

\section{Conclusion}

In Togo, apparently the regulation in this area is in force, preventing the entry of OCPs from neighboring countries. What characterizes the quite low levels of OCPs observed in most studied vegetables which never exceeded the residue levels of OCPs set by EU and FAO/WHO, indicating minimal risk to the consumers except for relatively high residue levels of $\Sigma \mathrm{HCHs}$ detected in tomato samples from the Prefecture de Tchaoudjo and in cabbage samples from Préfecture de Tchaoudjo, Préfecture de l'Ogou, Préfecture de Kloto and Préfecture de Danyi exceeding EU MRL and that could be supportive of a possible health risk for consumers. Thus strengthening the regulation, continuous monitoring of vegetables and extending to other vegetables are highly recommended in order to ensure consumers protection.

\section{Acknowledgements}

This study was fund by Union Economique et Monétaire Ouest-Africaine (UEMOA) and West African Agricultural Productivity Program (WAAPP/PPAAO)-Togo. Vegetable farmers and their extension staff in study areas are acknowledged for their field assistance.

\section{References}

[1] Bhanti, M. and Taneja, A. (2007) Contamination of Vegetables of Different Seasons with Organophosphorous Pesticides and Related Health Risk Assessment in Northern India. Chemosphere, 69, 63-68. http://dx.doi.org/10.1016/j.chemosphere.2007.04.071

[2] UNEP (2001) Final Act of the Conference of Plenipotentiaries on the Stockholm Convention on Persistant Organic Pollutants. Geneva, 44.

[3] Darko, G., Akoto, O. and Oppong, C. (2008) Persistent Organochlorine Pesticide Residues in Fish, Sediments and Water from Lake Bosomtwi, Ghana. Chemosphere, 72, 21-24. http://dx.doi.org/10.1016/j.chemosphere.2008.02.052

[4] Loganathan, B.G. (2012) Global Contamination Trends of Persistent Organic Chemicals: An Overview. In: Loganathan, B.G. and Lam, P.K.S., Eds., Global Contamination Trends of Persistent Chemicals, CRC Press, 638.

[5] Sudaryanto, A., Kunisue, T., Kajiwara, N., Iwata, H., Adibroto, T.A., Hartono, P. and Tanabe, S. (2006) Specific Accumulation of Organochlorines in Human Breast Milk from Indonesia: Levels, Distribution, Accumulation Kinetics and Infant Health Risk. Environmental Pollution, 139, 107-117. http://dx.doi.org/10.1016/j.envpol.2005.04.028

[6] Hedley, A.J., Hui, L.L., Kypke, K., Malisch, R., van Leeuwen, F.X., Moy, G., Wong, T.W. and Nelson, E.A. (2010) Residues of Persistent Organic Pollutants (POPs) in Human Milk in Hong Kong. Chemosphere, 79, 259-265. http://dx.doi.org/10.1016/j.chemosphere.2010.01.047

[7] Shoiful, A., Fujita, H., Watanabe, I. and Honda, K. (2013) Concentrations of Organochlorine Pesticides (OCPs) Residues in Foodstuffs Collected from Traditional Markets in Indonesia. Chemosphere, 90, 1742-1750. http://dx.doi.org/10.1016/j.chemosphere.2012.10.022

[8] Blocksom, K.A., Walters, D.M., Jicha, T.M., Lazorchak, J.M., Angradi, T.R. and Bolgrien, D.W. (2010) Persistent Organic Pollutants in Fish Tissue in the Mid-Continental Great Rivers of the United States. Science of the Total Environment, 408, 1180-1189. http://dx.doi.org/10.1016/j.scitotenv.2009.11.040

[9] Ueno, D., Isobe, T., Ramu, K., Tanabe, S., Alaee, M., Marvin, C., Inoue, K., Someya, T., Miyajima, T., Kodama, H. and Nakata, H. (2010) Spatial Distribution of Hexabromocyclododecanes (HBCDs), Polybrominated Diphenyl Ethers (PBDEs) and Organochlorines in Bivalves from Japanese Coastal Waters. Chemosphere, 78, 1213-1219. http://dx.doi.org/10.1016/j.chemosphere.2009.12.058 
[10] Moon, H.B., Kim, H.S., Choi, M., Yu, J. and Choi, H.G. (2009) Human Health Risk of Polychlorinated Biphenyls and Organochlorine Pesticides Resulting from Seafood Consumption in South Korea, 2005-2007. Food and Chemical Toxicology, 47, 1819-1825. http://dx.doi.org/10.1016/j.fct.2009.04.028

[11] Polder, A., Savinova, T.N., Tkachev, A., Loken, K.B., Odland, J.O. and Skaare, J.U. (2010) Levels and Patterns of Persistent Organic Pollutants (POPs) in Selected Food Items from Northwest Russia (1998-2002) and Implications for Dietary Exposure. Science of the Total Environment, 408, 5352-5361. http://dx.doi.org/10.1016/j.scitotenv.2010.07.036

[12] Qin, Y.Y., Leung, C.K., Leung, A.O., Zheng, J.S. and Wong, M.H. (2011) Persistent Organic Pollutants in Food Items Collected in Hong Kong. Chemosphere, 82, 1329-1336. http://dx.doi.org/10.1016/j.chemosphere.2010.12.009

[13] Amoah, P., Drechsel, P., Abaidoo, R.C. and Ntow, W.J. (2006) Pesticide and Pathogen Contamination of Vegetables in Ghana's Urban Markets. Archives of Environmental Contamination and Toxicology, 50, 1-6. http://dx.doi.org/10.1007/s00244-004-0054-8

[14] Bempah, C.K., Donkor, A., Yeboah, P.O., Dubey, B. and Osei-Fosu, P. (2011) A Preliminary Assessment of Consumer's Exposure to Organochlorine Pesticides in Fruits and Vegetables and the Potential Health Risk in Accra Metropolis, Ghana. Food Chemistry, 128, 1058-1065. http://dx.doi.org/10.1016/j.foodchem.2011.04.013

[15] Bempah, C.K., Buah-Kwofie, A., Enimil, E., Blewu, B. and Agyei-Martey, G. (2012) Residues of Organochlorine Pesticides in Vegetables Marketed in Greater Accra Region of Ghana. Food Control, 25, 537-542. http://dx.doi.org/10.1016/j.foodcont.2011.11.035

[16] Essumang, D.K., Dodoo, D.K., Adokoh, C.K. and Fumador, E.A. (2008) Analysis of Some Pesticide Residues in Tomatoes in Ghana. Human and Ecological Risk Assessment: An International Journal, 14, 796-806. http://dx.doi.org/10.1080/10807030802235243

[17] Essumang, D.K., Asare, E.A. and Dodoo, D.K. (2013) Pesticides Residues in Okra (Non-Target Crop) Grown Close to a Watermelon Farm in Ghana. Environmental Monitoring and Assessment, 185, 7617-7625. http://dx.doi.org/10.1007/s10661-013-3123-5

[18] Mawussi, G. (2008) Bilan environnemental de l'utilisation de pesticides organochlorés dans les cultures de coton, café et cacao au Togo et recherche d'alternatives par l'évaluation du pouvoir insecticide d'extraits de plantes locales contre le scolyte du café (Hypothenemus hampei Ferrari). Thèse de Doctorat, Université de Toulouse, France.

[19] Kuranchie-Mensah, H., Yeboah, P.O., Nyarko, E. and Golow, A.A. (2013) Studies on Organochlorine Pesticide Residue in Fishes from the Densu River Basin, Ghana. Bulletin of Environmental Contamination and Toxicology, 90, 421-426. http://dx.doi.org/10.1007/s00128-012-0931-1

[20] EU (2015) EU-Pesticides Database. http://ec.europa.eu/food/plant/pesticides/eu-pesticides-database/public

[21] WHO (2015) Pesticide Residue in Food and Feed. http://www.codexalimentarius.net/pestres/data/pesticides/index.html

[22] Kumar, B., Kumar, S., Mishra, M., Prakash, D., Singh, S.K. and Sharma, C.S. (2012) Persistent Chlorinated Pesticide Residues in Selected Market Vegetables of Root and Leaf Origin. Asian Journal of Plant Science and Research, 2, 232-236.

[23] Ananda Gowda, S.R. and Somashekar, R.K. (2012) Evaluation of Pesticide Residues in Farmgate Samples of Vegetables in Karnataka, India. Bulletin of Environmental Contamination and Toxicology, 89, 626-632. http://dx.doi.org/10.1007/s00128-012-0737-1

[24] Hu, W., Wang, T., Khim, J.S., Luo, W., Jiao, W., Lu, Y., Naile, J.E. and Giesy, J.P. (2010) Organochlorine Pesticides (HCHs and DDTs) in Soils along the North Coastal Areas of the Bohai Sea, China. Chemistry and Ecology, 26, 339352. http://dx.doi.org/10.1080/02757540.2010.504664

[25] Yang, R.Q., Lv, A.H., Shi, J.B. and Jiang, G.B. (2005) The Levels and Distribution of Organochlorine Pesticides (OCPs) in Sediments from the Haihe River, China. Chemosphere, 61, 347-354.

[26] Calvelo Pereira, R., Camps-Arbestain, M., Rodriguez Garrido, B., Macias, F. and Monterroso, C. (2006) Behaviour of $\alpha-, \beta$-, $\gamma$-, and $\delta$-Hexachlorocyclohexane in the Soil-Plant System of a Contaminated Site. Environmental Pollution, 144, 210-217. http://dx.doi.org/10.1016/j.envpol.2005.12.030

[27] Yang, R.Q., Jiang, G.B., Zhou, Q.F., Yuan, C.G. and Shi, J.B. (2005) Occurrence and Distribution of Organochlorine Pesticides (HCH and DDT) in Sediments Collected from East China Sea. Environmental International, 31, 799-804.

[28] Toan, V.D., Thao, V.D., Walder, J., Schmutz, H.R. and Ha, C.T. (2007) Contamination by Selected Organochlorine Pesticides (OCPs) in Surface Soils in Hanoi, Vietnam. Bulletin of Environmental Contamination Toxicology, 78, 195-200. http://dx.doi.org/10.1007/s00128-007-9149-z

[29] Pardo, F. and Maranon, E. (1997) Contaminacion oceanica de las plantas. In: Bueno, J.L., Sastre, H. and Lavin, S.G., Eds., Conatminacion e ingenierta ambiental, F.I.C.Y.T., Oviedo, Spain.

[30] Krauthacker, B., Romanica, S.H. and Reiner, E. (2001) Polychlorinated Biphenyls and Organochlorine Pesticides in Vegetation Samples Collected in Croatia. Bulletin of Environmental Contamination Toxicology, 66, 334-341. 
http://dx.doi.org/10.1007/s00128-001-0010-5

[31] Bempah, C.K. and Donkor, A.K. (2011) Pesticide Residues in Fruits at the Market Level in Accra Metropolis, Ghana, a Preliminary Study. Environment and Monitoring Assessment, 175, 551-561.

http://dx.doi.org/10.1007/s10661-010-1550-0 